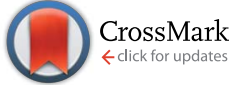

Cite this: RSC Adv., 2017, 7, 16087

Received 16th January 2017

Accepted 26th February 2017

DOI: 10.1039/c7ra00661f

rsc.li/rsc-advances

\title{
Novel alkyl chain-based fluorescent probes with large Stokes shifts used for imaging the cell membrane and mitochondria in different living cell lines $\dagger$
}

\author{
Fangfang Meng, Yong Liu, Jie Niu and Weiying Lin* \\ Fluorescent dyes with large Stokes shifts play a key role in developing multi-purpose fluorescent probes for \\ a wide variety of targets. In this study, we developed two novel alkyl chain-based fluorescent probes (CA- \\ C12 and CA-C2) with large Stokes shifts. The alkyl chain length of the probes affect the membrane \\ permeability, and hence both probes can be successfully applied for sensing the cell membrane and \\ mitochondria in different living cell lines. Furthermore, the probes CA-C12 and CA-C2 exhibited large \\ Stokes shifts and excellent photostability in the different cell lines. The fluorescent dyes with large Stokes \\ shifts were expected to have broader applications for developing various fluorescent probes with \\ excellent optical properties.
}

\section{Introduction}

The cell membrane is selectively permeable to various biological analyses and controls the movement of substances in and out of cells. ${ }^{1}$ The cell membrane covers the cytoplasm of living cells, physically separating the intracellular components from the extracellular environment. ${ }^{2}$ The cell membrane can regulate what enters and exits the cell, facilitating the transport of materials needed for survival. ${ }^{3}$ The cell membrane plays a key role in cell signal transduction and solute transporting. ${ }^{4-6}$ In addition, it plays an important role in anchoring the cell cytoskeleton and its attachment to the extracellular matrix and more cells to form tissues. ${ }^{7-9}$ Consequently, the search for a method of monitoring the cell membrane has always been attractive.

Mitochondria is also a membrane organelle and plays a key role in energy production through respiratory chains, ${ }^{\mathbf{1 0 - 1 2}}$ cell signalling via the production of reactive oxygen species, ${ }^{\mathbf{1 3}, \mathbf{1 4}}$ the regulation of $\mathrm{Ca}^{2+}$ homeostasis, ${ }^{15,16}$ and triggering cell death. ${ }^{17-20}$ Mitochondrial dysfunction is associated with intrinsic apoptotic pathways and causes a variety of neurodegenerative diseases including Alzheimer's disease, cancer and diabetes. $^{21-23}$ Therefore, it is of importance to image mitochondria in biological samples.

Institute of Fluorescent Probes for Biological Imaging, School of Materials Science and Engineering, School of Chemistry and Chemical Engineering, University of Jinan, Shandong 250022, P. R. China. E-mail: weiyinglin2013@163.com

$\dagger$ Electronic supplementary information (ESI) available: Experimental procedure, fluorescence spectra, tables and characterization data. See DOI: 10.1039/c7ra00661f
Compared to conventional technology, fluorescent probes have become powerful tools for detecting various targets in the environment, chemistry and medicine. ${ }^{24-26}$ Recently, a wide variety of fluorescent cell membrane and mitochondria probes have been engineered,,$^{27,28}$ but most of the cell membrane and mitochondria probes possessed small Stokes shifts; however, a small Stokes shift leads to fluorescence imaging errors of the probes in biological applications. ${ }^{29}$ Thus, the goal of our study is to design cell membrane and mitochondria probes with large Stokes shifts for imaging the cell membrane and mitochondria in different living cell lines.

As we know, carbazole derivatives show a number of attractive features including large Stokes shifts and excellent optical properties. $^{30,31}$ In this study, we have developed two novel alkyl chain-based fluorescent probes (CA-C2 and CA-C12) with large Stokes shifts based on a carbazole derivative (Fig. 1). It was found that both probes containing long and short alkyl chains can image the cell membrane and mitochondria in different living cell lines. We envisioned that the alkyl chain length affects the membrane permeability of the probes and indicated that the probes can real-time image the cell membrane and mitochondria in different living cell lines.

\section{Experimental}

\section{Measurements equipment and materials}

Unless otherwise stated, all reagents were purchased from commercial suppliers and used without further purification. Solvents were purified by standard methods prior to use. Doubly-distilled water was used throughout all the experiments. Mass spectra were recorded on a 6510 Q-TOF LC/MS or 
(a)

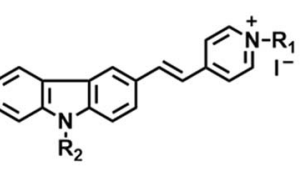

†CA-C12: $\mathrm{R}_{1}=-\mathrm{CH}_{2}-\left(\mathrm{CH}_{2}\right)_{10}-\mathrm{CH}_{3}$ $\mathrm{R}_{2}=-\mathrm{CH}_{2}-\left(\mathrm{CH}_{2}\right)_{16}-\mathrm{CH}_{3}$

$\theta$ CA-C2: $\mathbf{R}_{1}=\mathrm{R}_{2}=-\mathrm{CH}_{2}-\mathrm{CH}_{3}$

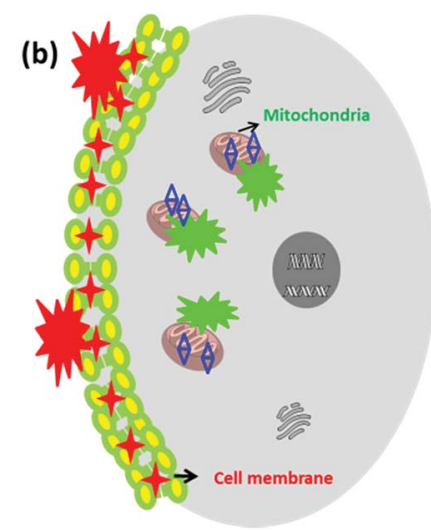

Fig. 1 (a) The structures of the probes $\mathrm{CA}-\mathrm{C} 2$ and $\mathrm{CA}-\mathrm{C} 12$, and (b) the overall strategy using probes $\mathrm{CA}-\mathrm{C} 2$ and $\mathrm{CA}-\mathrm{C} 12$ for imaging the cell membrane and mitochondria, respectively.

ThermoFisher LCQ FLEET. NMR spectra were recorded on a Bruker Avance 400 spectrometer using TMS as an internal standard. The UV-visible-near-IR absorption spectra were obtained on a Labtech UV Power PC spectrometer. Photoluminescent spectra were recorded on a HITACHI F-4600 fluorescence spectrophotometer with the excitation and emission slit widths at 5.0 and $5.0 \mathrm{~nm}$, respectively. Fluorescence imaging of the cells was performed using a Nikon A1MP twophoton confocal microscope. TLC analysis was performed on silica gel plates and column chromatography was conducted over silica gel (mesh 200-300), both of which were purchased from the Qingdao Ocean Chemicals. HeLa cells, A549 cells, 4T-1 cells and calf serum were obtained from the College of Life Science, Nankai University (Tianjin, China).

\section{Measurement of the fluorescence quantum yield}

The fluorescence quantum yields $(\Phi)$ were calculated using eqn (1):

$$
\Phi_{\mathrm{s}}=\Phi_{\mathrm{r}}\left(\frac{A_{\mathrm{r}}}{A_{\mathrm{s}}}\right)\left(\frac{n_{\mathrm{s}}{ }^{2}}{n_{\mathrm{r}}{ }^{2}}\right) \frac{I_{\mathrm{s}}}{I_{\mathrm{r}}}
$$

In this equation, the subscripts $\mathrm{s}$ and $\mathrm{r}$ refer to the sample and the reference molecule, respectively. $A$ is the absorbance of the molecules for both the sample and reference. $I$ represents the integrated emission area and $n$ is the refractive index of the solvent. $\Phi$ is the quantum yield.

\section{Preparation of the test solutions}

Stock solutions of the probes CA-C2 and CA-C12 were prepared at $1 \mathrm{mM}$ in DMF. Different solvents were used, including PBS, $\mathrm{H}_{2} \mathrm{O}, \mathrm{CHCl}_{3}$, DCM, DMF, DMSO, EtOH, MeOH, MeCN and THF. Test solutions of the probes CA-C2 and CA-C12 $(10 \mu \mathrm{M})$ in $5 \mathrm{~mL}$ of the different solvents were prepared. For the fluorescence spectra experiments, the excitation wavelength was $421 \mathrm{~nm}$ and the emission slit widths were $5 \mathrm{~nm}$ and $5 \mathrm{~nm}$.

\section{Cell culture and imaging}

Different types of cells (A549, 4T-1 and HeLa) were grown in Dulbecco's modified Eagle's medium, high glucose supplemented with penicillin/streptomycin and $10 \% \mathrm{FBS}$ in a $5 \% \mathrm{CO}_{2}$ incubator at $37{ }^{\circ} \mathrm{C}$. Before the imaging experiments, the cells were cultured overnight on a $35 \mathrm{~mm}$ Petri dish in order for their convenient observation. Cells were incubated with $10 \mu$ M CA-C2 and CA-C12 for $10 \mathrm{~min}$ at $37^{\circ} \mathrm{C}$, respectively. After being washed twice with PBS, the cells were imaged immediately. In the colocalization experiment, different cells were incubated with 2 $\mu \mathrm{M}$ commercially available mitochondrial probe MitoTracker Red (MTR) for $20 \mathrm{~min}$; after being washed three times with PBS, $10 \mu \mathrm{M}$ CA-C2 was added to the cells and incubated for $10 \mathrm{~min}$. Then, the cells were washed three times using PBS before imaging with a Nikon fluorescence microscope.

\section{Cell viability evaluated by MTT}

We used the colorimetric methyl cytotoxicity assay thiazolyl tetrazolium (MTT) assay on HeLa cells to measure in vitro cytotoxicity. About six thousand cells were seeded per well in a 96-well plate. After being incubated for $24 \mathrm{~h}$, different concentrations $(0,1,5,10,20$ and $30 \mu \mathrm{M})$ of the probes were added into each well. After $8 \mathrm{~h}$ of incubation, the cells were washed. Subsequently, $100 \mu \mathrm{L}$ of MTT ( $5 \mathrm{mg} \mathrm{mL}^{-1}$ ) was added to each well and further incubated for $4 \mathrm{~h}$. After removing the medium, $100 \mu \mathrm{L}$ of DMSO was added to each well to dissolve the purple crystals. Then, the absorbance at $570 \mathrm{~nm}$ was measured using a microplate reader.

\section{Results and discussion}

\section{Preparation of probe}

The chemical syntheses of CA-C2 and CA-C12 were accomplished in a total of four steps (Scheme 1). $N$-(2-Ethyl/dodecyl)-4-

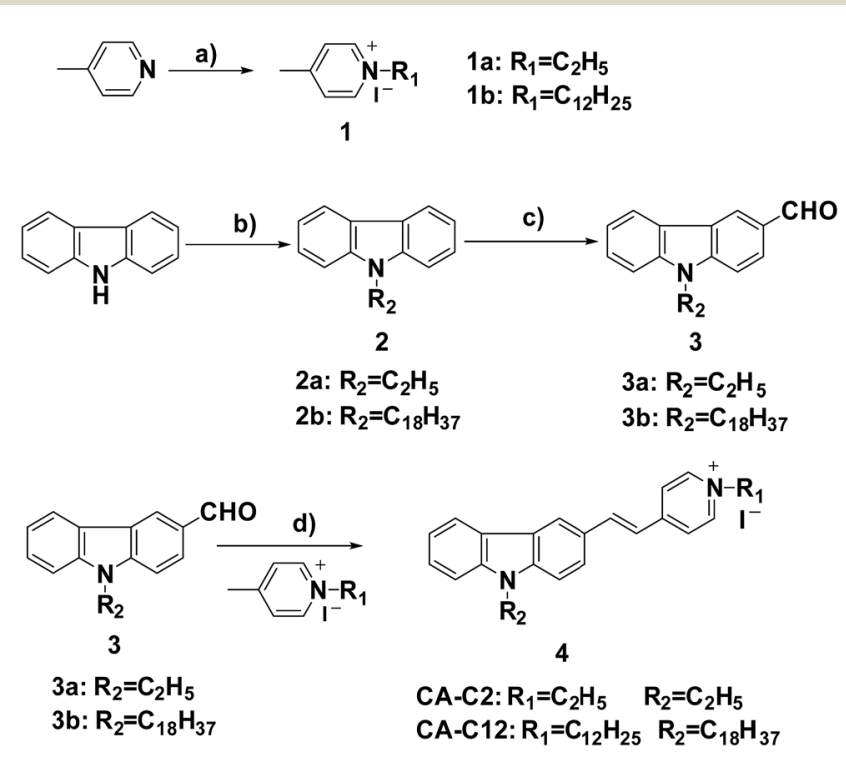

Scheme 1 The synthesis of the probes: (a) 1-bromooctadecane/ bromoethane, $\mathrm{KOH}, \mathrm{DMF}$, (b) $\mathrm{DMF}, \mathrm{POCl}_{3}$ and $\mathrm{CHCl}_{3}$, (c) 1-iodoundecane/iodoethane, EtOH, reflux and (d) EtOH, reflux. 
methylpyridinium iodide (1) and 9-ethyl/octadecyl-9H-carbazole (2) were prepared via an alkylation reaction. 9-Ethyl/octadecyl$9 H$-carbazole-3-carbaldehyde (3) was prepared in one step via the Vilsmeier reaction of compound (2) with phosphorus oxychloride. The target molecules CA-C2 and CA-C12 were obtained via a Knoevenagel condensation reaction between compound (3) and (1). The synthetic details of the products are given in the ESI. $\dagger$

\section{Optical properties}

To demonstrate the potential utility of CA-C2 and CA-C12 as suitable tracers for live-cell imaging, we evaluated the optical photophysical properties of both probes. As shown in Fig. 2 and $\mathrm{S} 1, \uparrow$ we found that the absorbance and emission spectra of CAC12 was similar to CA-C2 in various solutions. The maximum absorption of CA-C12 and CA-C2 was $430 \mathrm{~nm}$ (Fig. 2a and S1a †े) and $440 \mathrm{~nm}$ (Fig. 2c and S1c $\dagger$ ), respectively. CA-C12 and CA-C2 have an emission peak at $570-605 \mathrm{~nm}$ in various solutions, but the fluorescence intensities were very high in organic solvents compared to those in an aqueous solution (Fig. 2b, d, S1b and $\mathrm{d} \dagger$ ). The results demonstrate that compounds CA-C12 and CAC2 exhibited large Stokes shifts in various solutions (Table 1), which results in an efficient separation of the absorbance and emission maxima. The quantum yield $(\Phi)$ of the probes CA-C12 and CA-C2 was only 0.01-0.04 in an aqueous solution. In organic solvents, however, the maximum quantum yield of both probes reached 0.10-0.20 (Table 1).

As we know, mitochondria and the cell membrane are composed of different organic phases. Thus, we think that probes CA-C12 and CA-C2 may show strong fluorescence in the mitochondria or cell membrane. In addition, we further investigated the water solubility of the probes. ${ }^{32}$ The solubility of CAC12 and CA-C2 in water was $1.26 \mu \mathrm{M}$ and $3.6 \mu \mathrm{M}$, respectively. The results demonstrated that probe CA-C12 exhibited higher hydrophobicity than CA-C2 (Fig. S2†). Over a wide physiological $\mathrm{pH}$ range from 4.0 to 8.0 , the probes were found to be weakly fluorescent (Fig. 3), which demonstrated that CA-C12 and CA-C2 were not affected by $\mathrm{pH}$.
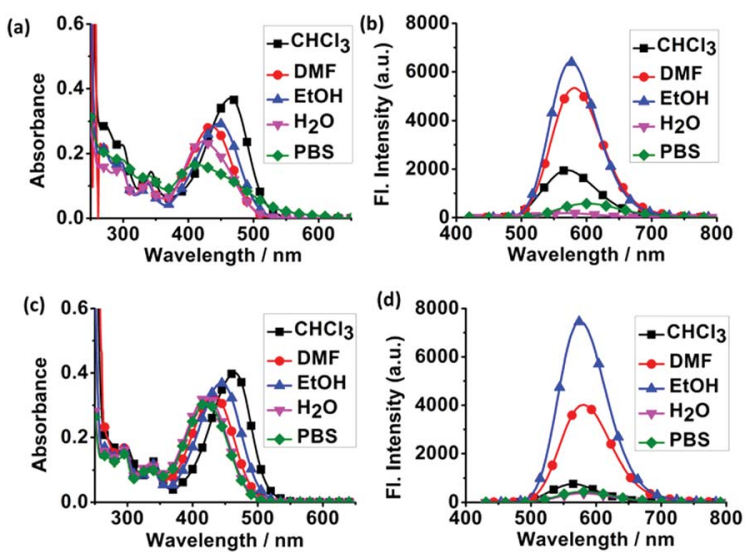

Fig. 2 The absorption and fluorescence spectra of CA-C12 ( $a$ and b) and $\mathrm{CA}-\mathrm{C2}$ (c and d) in various solvents. $\mathrm{CHCl}_{3}(\boldsymbol{\square}), \operatorname{DMF}(\mathbf{O}), \mathrm{EtOH}$ $(\boldsymbol{\Delta}), \mathrm{H}_{2} \mathrm{O}(\boldsymbol{\nabla})$ and PBS $(\bullet)$. [CA-C12] $=[\mathrm{CA}-\mathrm{C} 2]=10 \mu \mathrm{M}$.
Table 1 The photophysical properties of CA-C12/CA-C2 in various solvents

\begin{tabular}{|c|c|c|c|c|c|c|}
\hline \multirow[b]{2}{*}{ Sample } & \multirow[b]{2}{*}{$\begin{array}{l}\lambda_{\mathrm{a}}{ }^{a} / \lambda_{\mathrm{b}}{ }^{b} \\
(\mathrm{~nm})\end{array}$} & \multicolumn{2}{|c|}{ CA-C12 } & \multirow[b]{2}{*}{$\begin{array}{l}\lambda_{\mathrm{a}}{ }^{a} / \lambda_{\mathrm{b}}{ }^{b} \\
(\mathrm{~nm})\end{array}$} & \multicolumn{2}{|l|}{ CA-C2 } \\
\hline & & $\begin{array}{l}\mathrm{SS}^{c} \\
(\mathrm{~nm})\end{array}$ & $\Phi_{\mathrm{d}} / \%$ & & $\begin{array}{l}\mathrm{SS}^{c} \\
(\mathrm{~nm})\end{array}$ & $\Phi_{\mathrm{d}}(\%)$ \\
\hline PBS & $410 / 605$ & 195 & 3.56 & $421 / 581$ & 160 & 1.4 \\
\hline $\mathrm{H}_{2} \mathrm{O}$ & $420 / 573$ & 153 & 0.73 & $421 / 582$ & 161 & 1.1 \\
\hline $\mathrm{CHCl}_{3}$ & $465 / 570$ & 105 & 4.8 & $465 / 564$ & 99 & 1.6 \\
\hline DCM & $473 / 578$ & 105 & 15 & $470 / 575$ & 105 & 9.6 \\
\hline DMF & $430 / 580$ & 150 & 16 & $433 / 580$ & 147 & 11 \\
\hline DMSO & $432 / 583$ & 151 & 15 & $431 / 580$ & 149 & 20 \\
\hline EtOH & $445 / 575$ & 130 & 18 & $444 / 576$ & 132 & 18 \\
\hline $\mathrm{MeOH}$ & $442 / 578$ & 136 & 13 & $437 / 575$ & 138 & 11 \\
\hline MeCN & $437 / 582$ & 145 & 10 & $443 / 574$ & 131 & 13 \\
\hline THF & $437 / 576$ & 139 & 18 & $434 / 576$ & 142 & 14 \\
\hline
\end{tabular}

${ }^{a}$ Maximum absorption wavelength (nm). ${ }^{b}$ Maximum emission wavelength $(\mathrm{nm}) .{ }^{c}$ Stokes shift $(\mathrm{SS}) . \Phi_{\mathrm{d}}$ is the fluorescence quantum yield (error limit: $8 \%)$ determined using fluorescein $(\Phi=0.95)$ in aqueous $\mathrm{NaOH}$ (pH 13) as the standard.

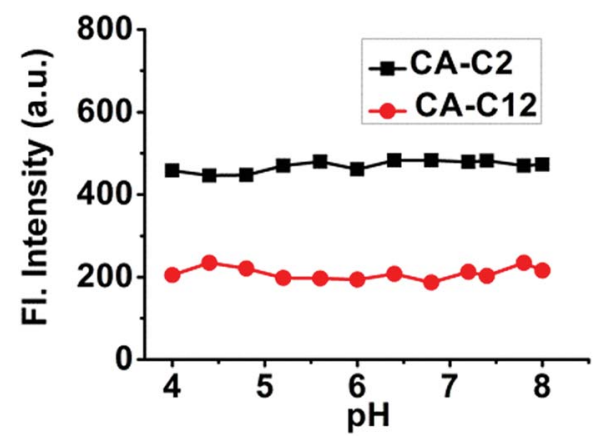

Fig. 3 The intensity of probes CA-C12 and CA-C2 in a buffer solution at different $\mathrm{pH}$ values. Excitation wavelength: $405 \mathrm{~nm}$. [CA-C12] $=$ $[\mathrm{CA}-\mathrm{C} 2]=2 \mu \mathrm{M}$.

\section{Cell membrane imaging and photostability}

To investigate the imaging of CA-C12 in living cell lines, fluorescence imaging experiments were carried out. The cytotoxicity was evaluated using standard MTT assays, indicating that the probe CA-C12 showed low toxicity to the cultured cells under the experimental conditions (Table S1 $\dagger$ ). Cancer cells (A549, 4T-1 and HeLa cells) were incubated with CA-C12 for $10 \mathrm{~min}$, followed by fluorescence microscopy. As shown in Fig. 4, the results of cells imaging demonstrated that the CA-C12 was located in the cell membrane and the probe was a cell membrane probe with poor permeability.

The photostability is one of the most important criteria for constructing novel fluorescence probes. ${ }^{33-36}$ Continuous scanning using a Nikon AMP1 confocal microscope was used to quantitatively investigate the photostability of CA-C12 $(10 \mu \mathrm{M})$. Within $360 \mathrm{~s}$, the fluorescence signals of CA-C12 decreased slightly in living HeLa cells (Fig. 5) and other living cells lines (Fig. S3†). The results proved that the probe CA-C12 was capable of real-time imaging cells membrane in different cell lines. 


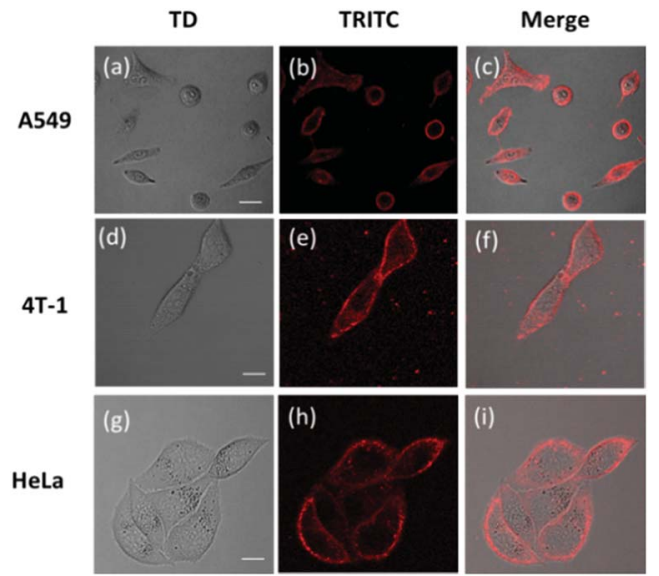

Fig. 4 (a-i) Confocal images of the probe CA-C12 $(10 \mu \mathrm{M})$ in different cells lines. $(a, d$ and $g$ ) Bright-field images, $(b$, e and $h$ ) fluorescence images of CA-C12 to the cell membrane $\left(\lambda_{\mathrm{ex}}=405 \mathrm{~nm} ; \lambda_{\mathrm{em}}=570-\right.$ $620 \mathrm{~nm}$ ) and (c, $f$ and i) merged images. Scale bar $=20 \mu \mathrm{m}$. (a)

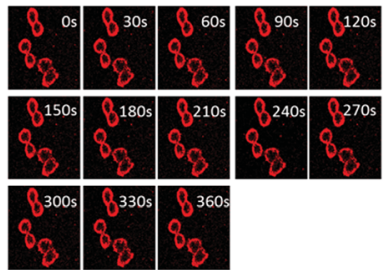

(b)

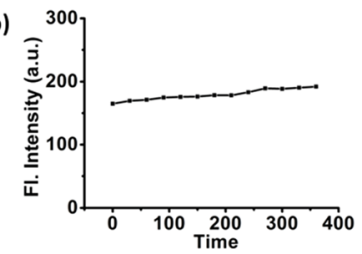

Fig. 5 (a) Fluorescence images (the red channel) of Hela cells incubated with CA-C12 acquired at different times under successive excitation. (b) The mean intensities of the cells incubated with CA-C12 $(10 \mu M)$ in the red channel under successive excitation at different times. Excitation wavelength: $405 \mathrm{~nm}$.

\section{Mitochondria imaging and photostability}

Contrary to the probe CA-C12 with a long alkyl chain, CA-C2 should possess superior permeability. Subsequently, we investigated whether CA-C2 can enter cells and image the mitochondria. Similarly, the cytotoxicity of CA-C2 was evaluated by MTT assays (Table S1 $\dagger$ ) and the data proved that CA-C2 had low toxicity towards living cells. As shown in Fig. 6, the probe CA-C2 possessed superior permeability to living cells and exhibited strong fluorescence in different living cells (A549, 4T-1 and HeLa cells).

Furthermore, to prove that the probe can image the mitochondria in different living cell lines, co-localization experiments were carried out. To determine the intracellular location of CA-C2 inside the cells, probe CA-C2 and the commercial mitochondrial tracker MTR were co-incubated in different cell lines (Fig. 7a-l). The intensity profile of the linear regions of interest across a HeLa cell in the green and red channels also varies in close synchrony (Fig. $7 \mathrm{j}-\mathrm{m}$ ). The Mander's overlap coefficient and Pearson's co-localization coefficient were determined as 0.95 and 0.90 , respectively (Fig. 7n). The imaging results demonstrate that probe CA-C2 was capable of imaging the mitochondria in different living cells lines. Similar to CA-C12, probe CA-C2 showed a high

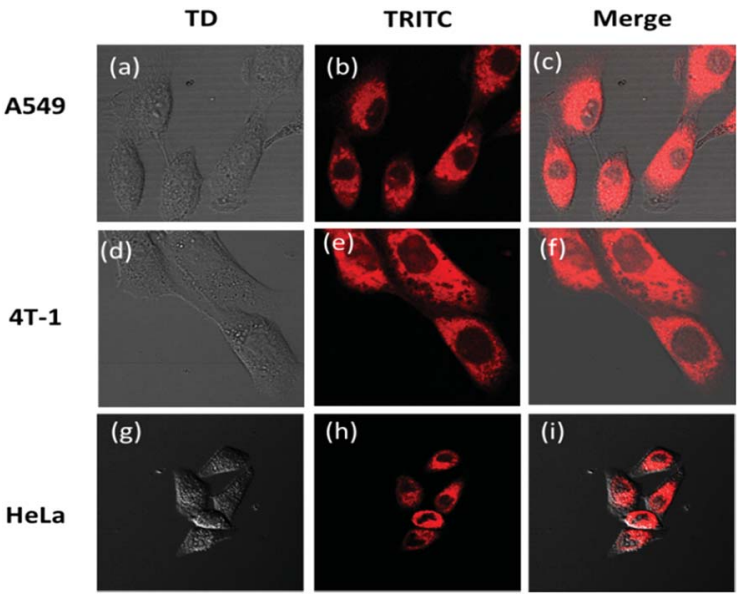

Fig. 6 (a-i) Confocal images of the different cells incubated with 10 $\mu \mathrm{M}$ probe CA-C2. ( $a, d$ and g) Bright-field images, (b, e and h) fluorescence images of CA-C2 $\left(\lambda_{\mathrm{ex}}=405 \mathrm{~nm} ; \lambda_{\mathrm{em}}=570-620 \mathrm{~nm}\right)$ and $(\mathrm{c}, \mathrm{f}$ and i) the merged images. Scale bar $=20 \mu \mathrm{m}$.

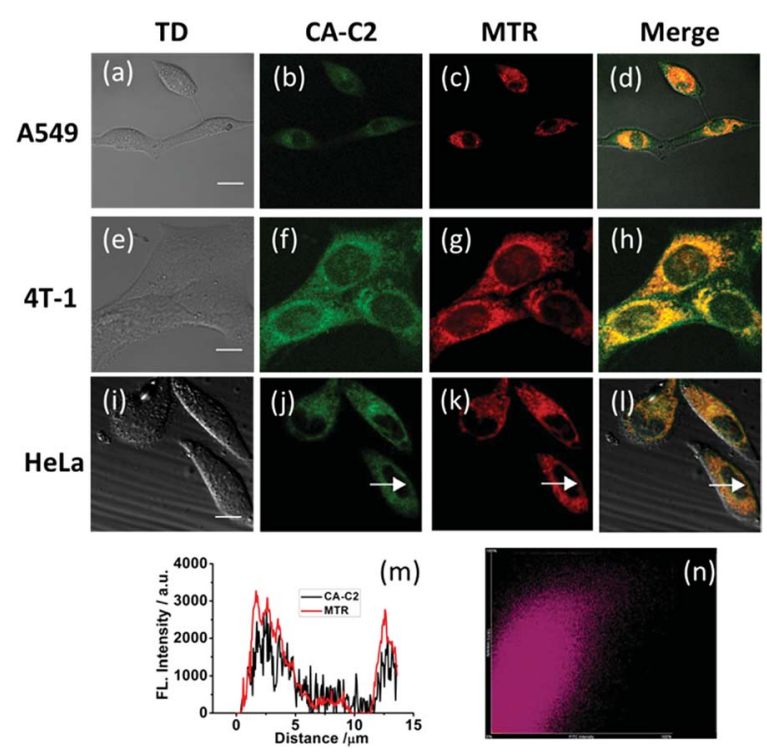

Fig. 7 The confocal images of cells treated with MTR $(2 \mu M)$ for $20 \mathrm{~min}$ and probe CA-C2 $(10 \mu \mathrm{M})$ for $10 \mathrm{~min}$. (a, e and i) Bright-field images, $(b, f$ and $j)$ fluorescence images of probe CA-C2 collected between 500 and $550 \mathrm{~nm}$ upon excitation at $405 \mathrm{~nm}$, (c, g and k) fluorescence images of MTR collected between 570 and $620 \mathrm{~nm}$ upon excitation at $561 \mathrm{~nm}$ and, ( $d, h$ and l) the merged images. (m) The intensity profile of the linear region of interest (white arrow) across the HeLa cells co-incubated with MTR and CA-C2. (n) The correlation plot of MTR and CA-C2 intensities. Scale bar = $20 \mu \mathrm{m}$.

fluorescence intensity within $360 \mathrm{~s}$ and this feature is promising as the probe can real-time image the mitochondria over a long period of time (Fig. 8). In addition, we further proved that probe CA-C2 possessed high photostability in living A549 and $4 \mathrm{~T}-1$ cells (Fig. $\mathrm{S} 4 \dagger$ ). 
(a)

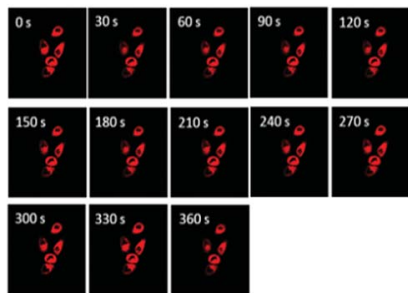

Fig. 8 (a) The fluorescence images (the red channel) of HeLa cells incubated with CA-C2 acquired at different times under successive excitation. (b) The mean intensities of the cells incubated with CA-C2 $(10 \mu M)$ in the red channel under successive excitation at different times. Excitation wavelength: $405 \mathrm{~nm}$.

\section{Conclusions}

In summary, we described two novel alkyl chain-based fluorescent probes (CA-C12 and CA-C2) with large Stokes shifts. The alkyl chain length of the probes affects the membrane permeability and allows both probes to be successfully applied for sensing the cell membrane and mitochondria in different living cell lines. Furthermore, probes CA-C12 and CA-C2 exhibited excellent photostability in different cell lines. This finding may open an avenue to engineer new fluorescent probes with improved optical properties.

\section{Acknowledgements}

This study was financially supported by the NSFC (21472067, 21672083 and 51503077), the Taishan Scholar Foundation (TS 201511041) and the startup fund of the University of Jinan (30910004) as well as the Doctor start up fund of University of Jinan (160082102) and NSFSP (ZR2015PE001).

\section{Notes and references}

1 K. Simons and E. Ikonen, Nature, 1997, 387, 569.

2 G. W. Feigenson, Annu. Rev. Biophys. Biomol. Struct., 2007, 36, 63.

3 L. Sherwood, Human Physiology: From cells to systems, West Publishing Company, New York, 1993.

4 B. Nichols, Nature, 2005, 436, 638.

5 Y. Lange, J. Ye and T. L. Steck, Biochemistry, 2007, 46, 2233. 6 H. Lodish, A. Berk, S. L. Zipursky, P. Matsudaira, D. Baltimore and J. Darnell, Molecular Cell Biology, Scientific American Book, New York, 4th edn, 2004.

7 M. R. Bernfield, S. D. Banerjee, J. E. Koda and A. C. Rapraeger, The role of extracellular matrix in development, New York, 1984. 8 S. K. Sastry and A. F. Horwitz, Curr. Opin. Cell Biol., 1993, 5, 819. 9 B. M. Gumbiner, Molecular Biology of the Cell, New York, 4th edn, 1996.

10 S. Anderson, A. T. Bankier, B. G. Barrell, M. H. L. D. Bruijin, A. R. Coulson, J. Drouin, I. C. Eperon, D. D. Nierlich,

B. A. Roe, F. Sanger, P. H. Schreier, A. J. H. Smith, R. Staden and I. G. Young, Nature, 1981, 290, 457.

11 S. W. Ballinger, J. M. Shoffner, E. V. Hedaya, I. Trance, M. A. Polak, D. A. Koontz and D. C. Wallace, Nat. Genet, 1992, 1, 11.

12 M. J. Bibb, V. R. A. Etten, C. T. Wright, M. W. Walberg and D. A. Clayton, Cell, 1981, 26, 167.

13 N. S. E. Chandel, E. Goldwasser, C. E. Mathien, M. C. Simon and P. T. Schumacker, Proc. Natl. Acad. Sci. U. S. A., 1998, 95, 11715.

14 A. Boveris, N. Oshino and B. Chance, Biochem. J., 1972, 128, 617.

15 M. F. Rossier, Cell Calcium, 2006, 40, 155.

16 R. Rizzuto, P. Pinton, W. Carrington, F. S. Fay, K. E. Fogarty, L. M. Lifshitz, R. A. Tuft and T. Pozzan, Science, 1998, 280, 1763.

17 N. Patil, D. R. Cox, D. Bhat, M. Faham, R. M. Myers and A. S. Peterson, Nat. Genet., 1995, 11, 126.

18 G. Kroemer and J. C. Reed, Nat. Med., 2000, 6, 513.

19 Q. F. Ahkong, D. Fisher, W. Tampion and J. A. Lucy, Nature, 1975, 253, 194.

20 D. R. Green and G. Kroemer, Science, 2004, 5684, 626.

21 M. T. Lin and M. F. Beal, Nature, 2006, 443, 787.

22 E. J. Lesnefsky, S. Moghaddas, B. Tandler, J. Kernerb and C. L. Hoppel, J. Mol. Cell. Cardiol., 2001, 33, 1065.

23 W. D. Parker, C. M. Filley and J. K. Parks, Neurology, 1990, 40, 1302.

24 M. Y. Berezin and S. Achilefu, Chem. Rev., 2010, 110, 2641.

25 H. Kobayashi, M. Ogawa, R. Alford, P. L. Choyke and Y. Urano, Chem. Rev., 2010, 110, 2620.

26 E. L. Que, D. W. Domaille and C. J. Chang, Chem. Rev., 2008, 108, 1517.

27 Y. Xia and L. Peng, Chem. Rev., 2013, 113, 7880.

28 A. R. Sarkar, C. H. Heo, H. W. Lee, K. H. Park, Y. H. Suh and H. M. Kim, Chem. Rev., 2015, 115, 5014.

29 H. Langhals, O. Krotz, K. Polborn and P. Mayer, Angew. Chem., Int. Ed., 2005, 44, 2427.

30 N. Blouin, A. Michaud, D. Gendron, S. Wakim, E. Blair, R. N. Plesu, M. Belletete, G. Durocher, Y. Tao and M. Leclerc, J. Am. Chem. Soc., 2008, 130, 732.

31 G. Zotti, G. Schiavon, S. Zecchin, J.-F. Morin and M. Leclerc, Macromolecules, 2002, 35, 2122.

32 H. M. Kim, B. H. Jeong, J.-Y. Hyon, M. J. An, M. S. Seo, J. H. Hong, K. J. Lee, C. H. Kim, T. Joo, S.-C. Hong and B. R. Cho, J. Am. Chem. Soc., 2008, 130, 4246.

33 B. P. Wittmershaus, J. J. Skibicki, J. B. McLafferty, Y. Z. Zhang and S. Swan, J. Fluoresc., 2001, 11, 119.

34 J. E. H. Buston, J. R. Young and H. L. Anderson, Chem. Commun., 2000, 11, 905.

35 B. R. Renikuntla, H. C. Rose, J. Eldo, A. S. Waggoner and B. A. Armitage, Org. Lett., 2004, 6, 909.

36 N. I. Shank, H. H. Pham, A. S. Waggoner and B. A. Armitage, J. Am. Chem. Soc., 2013, 135, 242. 